\title{
Interventions to prevent aspiration in older adults with dysphagia living in nursing homes: a scoping review
}

\author{
Shen Chen ${ }^{1}$, Bridie Kent ${ }^{2,3}$ and Yan Cui $^{1 *}$ (D)
}

\begin{abstract}
Background: Dysphagia is highly prevalent condition in older adults living in nursing homes. There is also evidence indicating that aspiration is one of the major health risks for these older adults, which is more likely to result in respiratory infections, aspiration pneumonia and sudden bolus death. Evidence syntheses have demonstrated the effectiveness of interventions for prevention of aspiration among hospitalized older people. The aim of this scoping review is to describe the current spread of interventions to prevent or reduce aspiration in older adults with dysphagia with a specific focus on those who reside in nursing homes.

Methods: The Joanna Briggs Institute methods and PRISMA-SCR guidelines were used to inform this review. MEDL INE, CINAHL, EMBASE, Cochrane Library, Joanna Briggs Institute EBP Database and Web of Science were searched for related articles from 2010 to 2020 as well as Chinese databases (CNKI, WANFANG DATA and VIP) and databases for unpublished material. A three-step search strategy was utilized, including the use of citation software to manage search results and de-duplication, abstract review and full-text review by two reviewers. Details of included studies were then extracted using a prepared data extraction tool. The resulting map was displayed in tabular form along with a narrative summary.
\end{abstract}

Results: Although 637 articles were located, 19 papers were included in the final analysis. Interventions to prevent aspiration in older adults with dysphagia living in nursing homes included: more bedside evaluation, modification of dietary, creating an appropriate environment for swallowing, providing appropriate feeding assistance, appropriate posture or maneuver for swallowing, appropriate rehabilitation program, medication treatment, and stimulation treatment.

Conclusion: Nursing homes, particularly those in developing countries, require more support for staff training and necessary equipment. Professional interventions provided by speech and language therapists are still limited in the setting of nursing homes. Modification of dietary was the most frequently used intervention to prevent or reduce aspiration. Multi-disciplinary interventions had the best results for aspiration management, but for many nursing homes, access to such teams is limited. Nursing home residents respond well to person-centered interventions that have a comprehensive consideration of their degree of aspiration risk, health condition, individual feelings and cognitive state.

Keywords: Aspiration, Aged, Resident, Dysphagia, Nursing homes, Scoping review

\footnotetext{
* Correspondence: cyan_njmu@163.com

${ }^{1}$ School of Nursing, Nanjing Medical University, Nanjing, China

Full list of author information is available at the end of the article
} which permits use, sharing, adaptation, distribution and reproduction in any medium or format, as long as you give appropriate credit to the original author(s) and the source, provide a link to the Creative Commons licence, and indicate if changes were made. The images or other third party material in this article are included in the article's Creative Commons licence, unless indicated otherwise in a credit line to the material. If material is not included in the article's Creative Commons licence and your intended use is not permitted by statutory regulation or exceeds the permitted use, you will need to obtain permission directly from the copyright holder. To view a copy of this licence, visit http://creativecommons.org/licenses/by/4.0/. The Creative Commons Public Domain Dedication waiver (http://creativecommons.org/publicdomain/zero/1.0/) applies to the data made available in this article, unless otherwise stated in a credit line to the data. 


\section{Background}

Dysphagia, which is highly prevalent in old age, was recognized as a geriatric syndrome by the European Union Geriatric Medicine Society, who defined it as a condition involving perceived, or real, difficulty in forming, or moving, a bolus safely from the oral cavity to the esophagus $[1,2]$. In short, it is a difficulty in swallowing. The prevalence of dysphagia in older adults, across different settings, has been calculated, with rates between 51 and $60 \%$ among institutionalized older adults, $44 \%$ in those admitted to geriatric acute care settings, and an average rate of $15 \%$ in the community dwelling older adults [1, 3-5]. According to these data, it is important to explore more fully the interventions that might help older adults who reside in institutions, such as nursing homes and residential care facilities, as they are more likely to suffer from dysphagia.

Most frequently, dysphagia is a result of altered physiology of deglutition caused by ageing, frailty, cancer of the neck and esophagus, or neurological diseases such as stroke, dementia and Parkinson disease [6-9]. Dysphagia is a serious condition that may lead to a decline in quality of life and is associated with many poor outcomes [10]. These include impaired swallowing efficacy, or the ineffective ingestion of nutrients and liquids, may cause malnutrition and/or dehydration [11, 12]. An impaired safety mechanism of swallowing, which can result in airway invasion, may lead to a complication called aspiration $[11,13,14]$. All these negative outcomes result in increased rates of hospitalization, hospital readmission, psychological distress and mortality $[1,14,15]$.

Aspiration has been defined as the misdirection of oropharyngeal or gastric contents into the larynx and lower respiratory tract [16]. It is one of the major health risks for older adults with dysphagia. Through the use of the gold standard test for aspiration, Video Fluoroscopic Swallowing Study (VFSS), the prevalence of aspiration has been calculated to be between 43 and $51 \%$ in people with dysphagia [17, 18]. In addition, 55 to $59 \%$ of this population were diagnosed as having silent aspiration, where solids or liquids were aspirated into their airways with no cough or shortness of breath, because of impairment of the cough reflex $[17,18]$. Such people are more likely to suffer from severe outcomes such as respiratory infections, aspiration pneumonia and sudden bolus death $[11,13,14]$. Previous studies showed that people who suffered long periods of time of aspiration had a significantly higher risk of death within 1 year than those with no aspiration [19-21]. Although the complications of dysphagia and aspiration can be severe, they are often undetected and untreated [22]. Therefore, it is very important and necessary to explore some interventions to avoid or reduce aspiration.
A preliminary review of the literature found that the scope of existing interventions to prevent aspiration in dysphagia people has not been fully captured. In particular, as nursing homes report a higher proportion of older adults with dysphagia than other settings, and they seldom have professional intervention equipment or similar ratios of healthcare staff to clients, when compared with hospitals, it was clear that, it was important to understand the extent of possible interventions suitable for implementation in nursing homes and residential care facilities. Therefore, this scoping review focused on all nursing homes settings and aimed to describe the current evidence on interventions to prevent or reduce aspiration in older adults with dysphagia who reside in these settings. By doing so, it may then help healthcare professionals and caregivers to identify the most appropriate approaches to avoid complications caused by aspiration and improve quality of life for older adults with dysphagia.

A peer reviewed protocol guided the implementation of this scoping review.

\section{Methods}

The JBI methodology for scoping reviews [23] was used. Reporting guidelines Preferred Reporting Items for Systematic Reviews and Meta-Analyses extension for Scoping Reviews (PRISMA-SR) were adhered [24].

\section{Review question}

What interventions are available to prevent or reduce aspiration in older adults with dysphagia who live in nursing homes or residential facilities?

\section{Inclusion criteria \\ Participants}

This scoping review only included older adults with dysphagia who lived in nursing homes or residential facilities. Older adults were defined as people aged 60 years or older, as this standard is used by many developing countries, and can cover the standard of 65 years or older.

\section{Concept}

These included all interventions designed to prevent aspiration for older adults with dysphagia who reside in a nursing home setting. All types of interventions, intervention providers, target residents of intervention, locations of intervention, and results of intervention were included as concepts.

\section{Context}

The context included interventions that occurred in all countries and were provided by both healthcare 
professionals and/or formal or informal caregivers and limited to nursing homes or residential facilities.

\section{Types of sources}

In order to be inclusive, both experimental and observational quantitative studies including randomized controlled trials, non-randomized controlled trials, quasiexperimental, before and after studies, prospective and retrospective cohort studies, case control studies, and analytical and descriptive cross-sectional studies were considered for inclusion. This scoping review also considered qualitative designs such as phenomenology, grounded theory, ethnography, action research and feminist research.

\section{Exclusion criteria}

Exclusions were interventions for adults under 60 years of age and interventions provided for people with esophageal dysphagia or without dysphagia, such as an intervention designed for people with aspiration caused by gastroesophageal reflux. People being cared for in hospital, community day centers or their own homes were also excluded; as were non-English studies, with the exception of Chinese language. JBI Manual allows restrictions on source inclusion by language when there are feasibility reasons. Our authors only have the ability to read English and Chinese.

\section{Search strategy}

A search strategy was developed, with assistance from an information scientist, and it aimed to find both published and unpublished studies over the last 10 years from 2010 to 2020, in order to capture the most up-todate evidence. An initial limited search of MEDLINE and CINAHL using preliminary keywords was firstly undertaken to identify articles on the topic. The preliminary keywords include: dysphagia, swallowing disorder, swallowing difficulty, aspiration, airway invasion, nursing homes, residential care facilities, older adults, the elderly, intervention and management.

The databases to be searched for published material include: MEDLINE, CINAHL, EMBASE, Cochrane Library, Joanna Briggs Institute EBP Database and Web of Science. The search terms included $\mathrm{MeSH}$ and "free text" terms in combination. Chinese databases included: CNKI (https://www.cnki.net/), WANGFAN DATA (http://www.wanfangdata.com.cn/index.html) and VIP (http://qikan.cqvip.com/). The databases for unpublished material included Open Grey, British Library, CADTH, EThOS, MedNar, TRIP Database and Google Scholar.

The text words contained in the titles and abstracts of relevant articles, and the index terms used to describe the articles were extracted. A full secondary search was then performed using the terms identified from the initial review results. Full search strategy is provided in Appendix 1. References from retrieved articles were then searched for additional studies for the final stage of the process.

\section{Title and abstract screening}

Citation management software EndNote X9 (Clarivate Analytics, PA, USA) was used to manage the list of all citations retrieved and all unnecessary duplicate records were eliminated. Two independent reviewers screened the title and abstract of each article to determine its relevance to the inclusion criteria. Potentially relevant studies were retrieved in full and their citation details imported into the Joanna Briggs Institute System for the Unified Management, Assessment and Review of Information (JBI-SUMARI; JBI, Adelaide, Australia). The full text of selected citations was assessed in detail against the inclusion criteria by two independent reviewers. Reasons for exclusion were documented. Any disagreements that arise between the reviewers at each stage of the study selection process were resolved through discussion.

\section{Data extraction}

A modified JBI data extraction tool was developed by the reviewers; the extraction tool is listed in Appendix 2. The data extracted included specific details about the population, concept, context, study methods and key findings relevant to the review objective such as: types of interventions, intervention providers, target residents of intervention, locations of intervention, results of intervention.

\section{Results}

The literature search resulted in a total of 446 citations after duplicates were removed. The titles and abstracts for these citations were screened and 81 citations were considered for further detailed assessment of the full paper. After further screening, 29 were excluded for not being in settings of nursing homes, 27 were excluded for not being related to interventions to prevent aspiration, 6 were excluded for not being studies conducted among older adults, and 1 was excluded for not being written in English or Chinese. Subsequently, 19 papers were identified for data extraction, including one of which was identified via grey literature and reference lists. A flow chart showing the number of citations at each stage is described in Fig. 1.

\section{Country or region for publication}

As Table 1 shows, of the nineteen studies [13, 25-42], six were conducted in the USA, three were conducted in Japan, two were conducted in Australia, and one was conducted in the UK, France, Sweden, Brazil, South Korea, Mainland China, Hongkong and Taiwan, respectively. Most were conducted in developed countries or regions (89.5\%). 


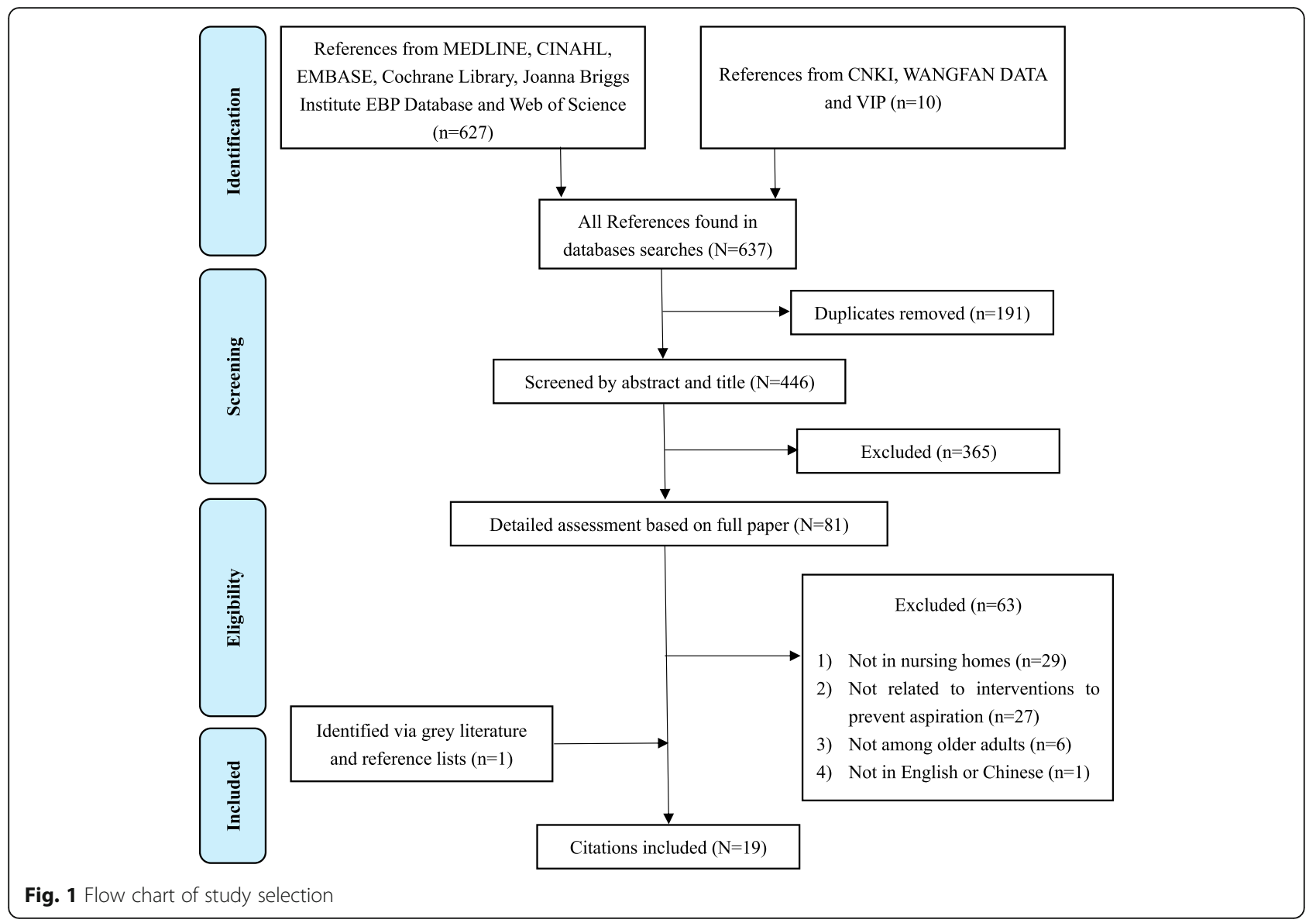

\section{Study design}

As Table 1 shows, only one study used a qualitative design [41], and the topic was related to feeding experiences from nursing aides. Two studies were randomized controlled trials $[29,42]$. Three were classified as pseudo randomized controlled trials and another three were quasi-experimental studies [25, 31, 34, 37, 39, 40]. Observational design was used in one study [27]. Of the six reviews, four were literature reviews and the other were systematic reviews [13, 32, 33, 35, 36, 38]. A further two studies utilized case series approaches and one was case report $[26,28,30]$.

\section{Target residents of intervention}

As Table 1 shows, one study reported its targets of intervention are frail residents [25]. Several studies included residents with specific diseases as intervention targets. Two studies mentioned Parkinson's disease $[28,30]$, another two included post-stroke older adults $[28,38]$ and a further four included residents with dementia [26, 27, 35, 36]. Only one study included residents with swallowing problems related to aging [28]. Eleven studies introduced their targets of intervention as residents with varying degrees of swallowing problems, but did not report the causes of dysphagia [13, 29, 31-34, 37, 39-42].

\section{Intervention providers}

As Table 1 shows, five studies used an interdisciplinary team as their intervention providers $[25,34,37,38,40]$, which meant that residents with dysphagia experienced multiple interventions from two or more kinds of professionals. Five studies reported their intervention providers to be nurses $[13,25,34,37,40]$, two included nursing assistants or aides [27, 41], and five included speechlanguage therapists $[25,26,29,34,38]$. In addition, nine studies only indicated that the interventions were conducted by nursing home staff without clarifying their specific occupations [28, 30-33, 35, 36, 39, 42].

\section{Interventions}

As Table 2 shows, the interventions from included studies can be classified into eight groups. As Fig. 2 indicates, modification of dietary, appropriate feeding assistance, appropriate posture or maneuver for swallowing and rehabilitation program were the most frequently reported among all included studies. 
Table 1 Summary of studies

\begin{tabular}{|c|c|c|c|c|c|}
\hline Authors (Year) & Study design & Setting & $\begin{array}{l}\text { Country } \\
\text { or region }\end{array}$ & Target residents of intervention & Intervention providers \\
\hline $\begin{array}{l}\text { Cormary X, et al. } \\
\text { (2018) [25] }\end{array}$ & $\begin{array}{l}\text { Quasi- } \\
\text { experimental } \\
\text { Study }\end{array}$ & Nursing home & France & Frail residents & $\begin{array}{l}\text { Nurses, speech therapists, doctors, } \\
\text { dentists, dieticians, a 3-star chef and } \\
\text { catering managers }\end{array}$ \\
\hline $\begin{array}{l}\text { Freiry AM, et al. } \\
\text { (2017) [26] }\end{array}$ & Case series & $\begin{array}{l}\text { Long stay } \\
\text { institution }\end{array}$ & Brazil & Dementia residents & Speech-language therapists \\
\hline $\begin{array}{l}\text { Gilmore-Bykovskyi } \\
\text { AL, Rogus-Pulia N. } \\
\text { (2018) [27] }\end{array}$ & $\begin{array}{l}\text { Observational } \\
\text { study }\end{array}$ & Nursing Home & USA & Dementia residents & Nursing assistants \\
\hline $\begin{array}{l}\text { Gokula M, et al. } \\
\text { (2011) [28] }\end{array}$ & Case series & $\begin{array}{l}\text { Long-term } \\
\text { care facility }\end{array}$ & USA & $\begin{array}{l}\text { Residents with prior stroke, Parkinson's } \\
\text { disease or swallowing problems } \\
\text { related to aging }\end{array}$ & Long-term care facility staff \\
\hline $\begin{array}{l}\text { Hagglund P, et al. } \\
\text { (2019) [29] }\end{array}$ & $\begin{array}{l}\text { Randomized } \\
\text { controlled trial }\end{array}$ & $\begin{array}{l}\text { Intermediate } \\
\text { care unit }\end{array}$ & Sweden & Residents with swallowing dysfunction & $\begin{array}{l}\text { Calibrated professionals (registered } \\
\text { dental hygienists and speech-language } \\
\text { pathologist) }\end{array}$ \\
\hline $\begin{array}{l}\text { Hajjar S, Wollman D. } \\
\text { (2019) [30] }\end{array}$ & Case report & Nursing home & USA & $\begin{array}{l}\text { Residents with Parkinson's disease } \\
\text { presented with aspiration pneumonia }\end{array}$ & Caregivers \\
\hline $\begin{array}{l}\text { Kuramoto N, et al. } \\
\text { (2018) [31] }\end{array}$ & $\begin{array}{l}\text { Quasi- } \\
\text { experimental } \\
\text { Study }\end{array}$ & Nursing home & Japan & Nursing home residents & Caregivers \\
\hline $\begin{array}{l}\text { Levenson SA, Walker } \\
\text { VL. (2019) [32] }\end{array}$ & $\begin{array}{l}\text { Literature } \\
\text { review }\end{array}$ & Nursing home & USA & Nursing home residents & Caregivers \\
\hline $\begin{array}{l}\text { Luk JKH, Chan DKY. } \\
\text { (2014) [33] }\end{array}$ & $\begin{array}{l}\text { Literature } \\
\text { review }\end{array}$ & $\begin{array}{l}\text { Residential } \\
\text { care home }\end{array}$ & $\begin{array}{l}\text { Hong } \\
\text { Kong }\end{array}$ & Nursing home residents & Caregivers \\
\hline $\begin{array}{l}\text { Mesioye A, et al. } \\
\text { (2018) [34] }\end{array}$ & $\begin{array}{l}\text { Quasi- } \\
\text { experimental } \\
\text { Study }\end{array}$ & $\begin{array}{l}\text { Veteran's } \\
\text { community } \\
\text { living center }\end{array}$ & USA & $\begin{array}{l}\text { Residents who were receiving } \\
\text { modified diets or required feeding } \\
\text { assistance }\end{array}$ & Interdisciplinary team \\
\hline $\begin{array}{l}\text { Morley JE. (2015) } \\
\text { [13] }\end{array}$ & $\begin{array}{l}\text { Literature } \\
\text { review }\end{array}$ & Nursing home & USA & Nursing home residents & Nurses and caregivers \\
\hline $\begin{array}{l}\text { Hines S, et al. (2010) } \\
\text { [35] }\end{array}$ & $\begin{array}{l}\text { Systematic } \\
\text { review }\end{array}$ & $\begin{array}{l}\text { Residential } \\
\text { aged care } \\
\text { facility }\end{array}$ & Australia & Dementia residents & Caregivers \\
\hline $\begin{array}{l}\text { Painter V, et al. } \\
\text { (2017) [36] }\end{array}$ & $\begin{array}{l}\text { Systematic } \\
\text { review }\end{array}$ & $\begin{array}{l}\text { Residential } \\
\text { aged care } \\
\text { facility }\end{array}$ & Australia & Dementia residents & Caregivers \\
\hline $\begin{array}{l}\text { Park Y, et al. (2015) } \\
\text { [37] }\end{array}$ & $\begin{array}{l}\text { Pseudo } \\
\text { Randomized } \\
\text { Controlled Trial }\end{array}$ & Nursing home & $\begin{array}{l}\text { South } \\
\text { Korea }\end{array}$ & Nursing home residents & $\begin{array}{l}\text { Geriatric care workers, social workers } \\
\text { and nurses }\end{array}$ \\
\hline $\begin{array}{l}\text { Richards E. (2012) } \\
\text { [38] }\end{array}$ & $\begin{array}{l}\text { Literature } \\
\text { review }\end{array}$ & Nursing home & UK & $\begin{array}{l}\text { Residents with swallowing and } \\
\text { communication difficulties after stroke }\end{array}$ & $\begin{array}{l}\text { Speech-language therapists and } \\
\text { nursing home staff }\end{array}$ \\
\hline $\begin{array}{l}\text { Yamada T, et al. } \\
\text { (2017) [39] }\end{array}$ & $\begin{array}{l}\text { Pseudo } \\
\text { Randomized } \\
\text { Controlled Trial }\end{array}$ & Nursing home & Japan & Nursing home residents & Researchers \\
\hline $\begin{array}{l}\text { Lu M, et al. (2018) } \\
\text { [40] }\end{array}$ & $\begin{array}{l}\text { Pseudo } \\
\text { Randomized } \\
\text { Controlled Trial }\end{array}$ & Nursing home & China & Residents with dysphagia & Nurses and general practitioners \\
\hline $\begin{array}{l}\text { Chiang CK, Hwu YJ. } \\
\text { (2018) [41] }\end{array}$ & $\begin{array}{l}\text { Qualitative } \\
\text { study }\end{array}$ & $\begin{array}{l}\text { Long-term } \\
\text { care facility }\end{array}$ & Taiwan & Nursing aides & Nursing aides \\
\hline $\begin{array}{l}\text { Takamoto K, et al. } \\
\text { (2017) [42] }\end{array}$ & $\begin{array}{l}\text { Randomized } \\
\text { Controlled Trial }\end{array}$ & $\begin{array}{l}\text { Elder care } \\
\text { facility }\end{array}$ & Japan & Nursing home residents & The facility staff and experimenters \\
\hline
\end{tabular}

\section{More bedside evaluation}

Conducting more bedside evaluation was mentioned in three studies to avoid some inappropriate care delivered by caregivers during mealtime. Thus, nursing home staff screened the risk of complication, evaluated the individualized menu and laminated cards kept in the dining areas, grouped by the degree of dysphagia risk, and then gave a quick check on symptoms and signs such as coughing, drooling, making a grunting sound during mealtime [25, 34, 37]. 
Table $\mathbf{2}$ Interventions and the articles that refer to them

\begin{tabular}{|c|c|c|c|c|c|c|c|c|}
\hline Authors (Year) & $\begin{array}{l}\text { More bedside } \\
\text { evaluation }\end{array}$ & $\begin{array}{l}\text { Modification } \\
\text { of dietary }\end{array}$ & $\begin{array}{l}\text { Appropriate } \\
\text { environment } \\
\text { for swallowing }\end{array}$ & $\begin{array}{l}\text { Appropriate } \\
\text { feeding } \\
\text { assistance }\end{array}$ & $\begin{array}{l}\text { Appropriate } \\
\text { posture or } \\
\text { maneuver for } \\
\text { swallowing }\end{array}$ & $\begin{array}{l}\text { Rehabilitation } \\
\text { program }\end{array}$ & $\begin{array}{l}\text { Medication } \\
\text { treatment }\end{array}$ & $\begin{array}{l}\text { Stimulation } \\
\text { treatment }\end{array}$ \\
\hline $\begin{array}{l}\text { Cormary X, et al. (2018) } \\
\text { [25] }\end{array}$ & * & & & * & * & & & \\
\hline $\begin{array}{l}\text { Freiry AM, et al. (2017) } \\
\text { [26] }\end{array}$ & & & & & & * & & \\
\hline $\begin{array}{l}\text { Gilmore-Bykovskyi AL, } \\
\text { Rogus-Pulia N. (2018) } \\
\text { [27] }\end{array}$ & & & & * & & & & \\
\hline $\begin{array}{l}\text { Gokula M, et al. (2011) } \\
\text { [28] }\end{array}$ & & & & & & & * & \\
\hline $\begin{array}{l}\text { Hagglund P, et al. } \\
\text { (2019) [29] }\end{array}$ & & & & & & * & & \\
\hline $\begin{array}{l}\text { Hajjar S, Wollman D. } \\
\text { (2019) [30] }\end{array}$ & & * & & & & & & \\
\hline $\begin{array}{l}\text { Kuramoto N, et al. } \\
\text { (2018) [31] }\end{array}$ & & & & & * & & & \\
\hline $\begin{array}{l}\text { Levenson SA, Walker } \\
\text { VL. (2019) [32] }\end{array}$ & & * & & & & & & \\
\hline $\begin{array}{l}\text { Luk JKH, Chan DKY. } \\
\text { (2014) [33] }\end{array}$ & & * & * & & * & & * & * \\
\hline $\begin{array}{l}\text { Mesioye A, et al. (2018) } \\
\text { [34] }\end{array}$ & * & * & * & & & & * & \\
\hline Morley JE. (2015) [13] & & * & & * & * & & & * \\
\hline $\begin{array}{l}\text { Hines S, et al. (2010) } \\
\text { [35] }\end{array}$ & & * & & & & & & \\
\hline $\begin{array}{l}\text { Painter V, et al. (2017) } \\
\text { [36] }\end{array}$ & & * & & & & & & \\
\hline Park Y, et al. (2015) [37] & * & * & & $*$ & * & * & & \\
\hline Richards E. (2012) [38] & & * & & $*$ & * & * & & * \\
\hline $\begin{array}{l}\text { Yamada T, et al. (2017) } \\
\text { [39] }\end{array}$ & & * & & & & & & \\
\hline Lu M, et al. (2018) [40] & & * & * & $*$ & & * & & \\
\hline $\begin{array}{l}\text { Chiang CK, Hwu YJ. } \\
\text { (2018) [41] }\end{array}$ & & * & & * & * & & & \\
\hline $\begin{array}{l}\text { Takamoto K, et al. } \\
\text { (2017) [42] }\end{array}$ & & & & & & * & & \\
\hline
\end{tabular}

\section{Modification of dietary}

Twelve studies reported that modification of dietary consistency or texture was a commonly used method in nursing homes to prevent or reduce aspiration [13, 30, 3241]. Such modification usually involved the use of thickening agents to change the consistency of food or fluids. Of these studies, seven used this intervention as a part of an interdisciplinary prevention plan $[13,33,34,37,38,40,41]$; the others focused on it to explore its independent effects $[30,32,35,36,39]$. Most of studies concluded that texturemodified food and liquids reduced the risk of aspiration, and that this was helpful in maintaining adequate fluid intake for residents with dysphagia. However, Levenson reported that no clear correlation was found between viscosity and successful prevention of aspiration pneumonia [32]. Painter also reported that food consistency change was useful in reducing the risk of aspiration seen on video fluoroscopy, but little evidence supported the use of texture-modified food to improve the clinical consequence of aspiration pneumonia [36]. In addition, Richards reported that strengthening taste, such as by using sour drink or food, was helpful in improving the delayed onset of oral movement and swallow, which might be a useful strategy to reduce the risk of aspiration [38].

\section{Appropriate environment for swallowing}

Three studies reported that the eating environment might influence the risk of aspiration. Luk suggested 


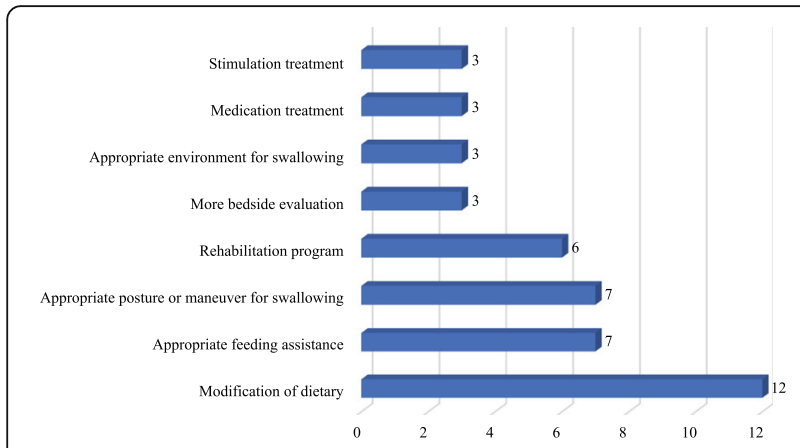

Fig. 2 Frequency of reporting of interventions

that nursing homes should provide a quiet environment without distraction during mealtime [33]. Mesioye reported that environmental factors, such as dining room lighting, should be considered [34]. Lu advised that appropriate tableware is also very important [40].

\section{Appropriate feeding assistance}

Seven studies reported that using appropriate skills and equipment to assist residents to have meals could reduce the risk of aspiration. The skills included behaviors such as feeding slowly and adjusting the rate to the resident's pace, modifying the volume of bolus or fluid when feeding, direct eye-contact, showing approval, orientation, providing choices, asking the resident for cooperation and giving appropriate emergency treatment for aspiration [13, 25, 27, $37,38,40,41]$. Regarding the equipment, it was only mentioned that appropriate adaptive equipment should be available, but no specific equipment was reported $[13,25]$.

\section{Appropriate posture or maneuver for swallowing}

Seven studies suggested that using appropriate postures or maneuvers could prevent aspiration when eating or drinking $[13,25,31,33,37,38,41]$. For those who can get out of bed, caregivers should help them sit upright when eating [33]. For those who are not able to get out of bed, it is important to raise the head of the bed by at least 30 degrees [33]. Tucking the chin toward the chest, which has also been called chin-tuck or chin-down, can prevent bolus or liquid from entering the airway [13, 33, 38]. Turning the head towards the paralyzed side and tilting the body to the non-paralyzed side is recommended as these actions makes it easier and safer to direct the food or fluid bolus downward and pass through the weaker side $[33,38]$. In order to inform residents about an appropriate posture adjustment, Kuramoto developed a smartphone-based neck worn swallowing monitor, which was found to enhance safer mealtime assistance with less risk of aspiration [31].

Some swallowing maneuvers are also useful in strengthening swallowing function and preventing or reducing aspiration. Luk and Richards suggested that caregivers should guide residents to use some or all of the following: double or multiple swallowing, hard swallowing, effortful swallowing, repeated head lift maneuver, supraglottic swallowing (technique to hold breath, then swallow, then cough), Masako maneuver (holding tongue in teeth and dry swallowing) and Mendelsohn maneuver (prolonging upper position of larynx during swallow) $[33,38]$.

\section{Swallowing rehabilitation program}

Six studies used different kinds of swallowing rehabilitation programs to reduce aspiration by improving swallowing function [26, 29, 37, 38, 40, 42]. Freiry conducted a four-week cryotherapy therapy and found that all participants improved their gag reflex sensitivity and reduced reflex swallowing time, indicating that the risk of aspiration was decreased [26]. Hagglund provided neuromuscular training of the pharyngeal and orofacial muscles for 5 weeks. At the end of the training period, aspiration signs were significantly reduced in the intervention group when compared with control group [29]. Takamoto guided participants to have a four-week lip closure training, and found the training was useful in reducing the risk of pulmonary aspiration [42]. The other three studies reported that tongue and oral exercises, neck muscle exercises, pursed-lip breathing, coughing exercises, oromotor exercises and vocal adduction exercises were effective in improving functional deglutition and enhancing impaired swallowing physiology. Furthermore, the risk of aspiration improved significantly after these rehabilitation programs $[37,38,40]$.

\section{Medication treatment}

Three studies reported that specific medications benefitted the swallowing ability of residents with dysphagia $[28,33,34]$. Gokula administered a $50 \mathrm{mg}$ to 100 mg daily dose of amantadine to 12 residents with swallowing problems. After using for 2 to 4 weeks, 11 patients demonstrated decreased cough while eating. After 4 to 6 weeks of use, these residents could gradually tolerate food without aspiration [28]. Luk introduced more medications which were able to improve the swallowing reflex, such as amantadine, levodopa, cilostazol, folate and angiotensin-converting enzyme inhibitors [33]. The author emphasized that it may be beneficial for older adults with dysphagia to continuously use angiotensin-converting enzyme inhibitor, if they have no intolerable cough [33]. When introducing the Interdisciplinary collaboration, Mesioye commented that physicians or pharmacists need to carefully review whether residents are taking medications that aggravate swallowing disorders [34]. 


\section{Stimulation treatment}

Of all the included studies, only three, which were literature reviews, reported that some neurostimulation approaches could reduce the risk of aspiration by improving swallowing function, based on the theory that thermal or mechanical stimulation at the anterior oropharynx can bring about reflex swallowing action [13, 33, 38]. These approaches included neuromuscular electrical stimulation, thermal tactile stimulation, repetitive transcranial magnetic stimulation to directly stimulate the pharyngeal motor cortex, and other chemical, physical or electrical stimulation to stimulate the peripheral oropharyngeal sensory system [13, 33, 38]. Previously, these approaches used to be only performed in hospitals, but with the upgrading and miniaturization of equipment, it is now possible that stimulation treatments can also be carried out in nursing homes [13].

\section{Discussion}

This scoping review included nineteen studies, with the majority conducted in developed countries or regions. There is a dearth of evidence from low to middle income countries, possibly because long-term care facilities in such countries are still at their early stage of development [43]. For example, China, the country with the largest ageing population in the world, only had approximately 7.5 million beds in nursing homes of the entire country [44]. Although the studies included in this review reported that their interventions were useful in preventing or reducing aspiration, theses intervention may not always suitable to be applied in developing countries, as these countries may not have sufficient resources such as well-trained nursing home staff and the necessary equipment [44].

Speech and language therapists (SLTs) perform an important role in the predominant management of dysphagia [26]. However, only five studies reported that their intervention providers included SLT teams [25, 26, 29, $34,38]$. Without the input of SLTs, nursing home may not be able to resolve some complicated problems related to their residents' swallowing function, and nursing home caregivers may not have the appropriate knowledge and skills to provide professional interventions for residents with dysphagia to reduce the risk of aspiration [44]. Limited by economic conditions, many nursing homes in developing countries are unable to hire SLT teams [44]. In many nursing homes, nurses are the sole registered health professionals, whilst in other residential care facilities, nursing assistants and other unregistered caregivers provide the essential care [45]. Therefore, residents with dysphagia in these institutions may experience repeated aspiration, and then suffer from severe aspiration pneumonia.
Modification of diet as an intervention was reported most frequently among all included studies, and it has been widely applied in many residential care facilities [46]. However, it is also one of the most controversial interventions. Few studies applied randomized controlled trail design and used video fluoroscopy or fiberoptic endoscopy to determine that the modification of diet can successfully prevent or reduce aspiration. Therefore, it has been questioned whether it is a reliable and justified intervention and whether it is necessarily better, as there is no strong evidence to show such methods reduce pneumonia [32, 36, 47]. It has been reported that modified diets and thickened liquids were often less palatable, and their texture and taste were strongly disliked by the residents [13, 32, 33]. Malnutrition, dehydration, subtherapeutic medication levels and reduced quality of life were common adverse consequences caused by modification of diet [13, 32, 33, 36]. Luk also indicated that liquids thickener is expensive, and blending and pureeing are labor-intensive [33]. Moreover, Carlisle reported that starch-thickened liquids had dangerous interaction with polyethylene glycol 3350 laxative (PEG) [48]. A precipitous loss of thickening happened when PEG was put into starch-based thickeners [48]. Therefore, if residents are using PEG, starch-based thickeners should be avoided when modifying diet. In addition, Ebihara reported that the reflex of swallowing was delayed seriously at body temperature [49]. Therefore, meals should be prepared immediately prior to eating, and pre-made food should be properly heated.

Using specific postures or maneuvers was also a popular intervention in many studies. They are very easy to learn and do not need great efforts [50]. However, many older adults who have cognitive impairment cannot follow such instructions of chin-tuck or chin-down [51, 52]. Swallowing postures and maneuvers do not always work for older people who suffer with dysphagia. Chintuck or chin-down was shown to help avoid aspiration in about $55 \%$ of cases, whilst a head-turned posture only worked for $25.3 \%$ [50, 51]. The effectiveness of chintuck, chin-down and head-turned posture are not good enough to prevent aspiration. Hence, aspiration may still happen frequently when using these approaches.

To prevent or reduce aspiration, a single intervention is often not enough. Many studies used an interdisciplinary team to provide, for residents with dysphagia, a multi-disciplinary prevention plan $[25,34,37,38,40]$. Direct interventions such as diet modification and chintuck or chin-down posture, which are usually used during the feeding process, are very easy and convenient to apply [1]. However, they are not the permanent solution. Indirect interventions such as rehabilitation programs that focus on exercising specific muscles or muscle groups, stimulation treatment and pharmacological 
treatment can reduce aspiration by improving swallowing function [53-56], although there is a case series questioned the effect of thermal-tactile stimulation [57]. But they usually take a long time with slow effects, and they cannot be used alone in the absence of direct interventions. Oral care has also been indicated as an indirect intervention that can help prevent aspiration pneumonia [58]. However, oral care is an adjuvant intervention and one that all older people should receive. Interdisciplinary interventions have a huge advantage in aspiration management. Based on the included studies, the interdisciplinary team usually contained part of or all of the following members: speech and language therapists, doctors, dentists, nurses, nursing assistants, care workers, social workers, dieticians, chefs and catering managers $[25,34,37,38,40]$. Consequently, the costs are high for interventions provided by so many specialists and it may be unacceptable for residents, especially those in developing countries, to pay a lot of money to acquire the multi-disciplinary services [44]. Thus, when providing intervention services, the feelings, needs and payment levels of residents should also be taken into account by nursing homes.

In this review, only two studies were standard randomized controlled trials and another two were systematic review. Therefore, many studies did not use high quality study designs, which may cause some bias and limit the reliability of the conclusion that their interventions were useful.

Many of existing interventions do not appear to be suitable for residents who have dysphagia and cognitive impairment. Such people find is much harder to follow the instructions from intervention providers [50, 51]. Feeding tubes are frequently used to ensure enough nutrition intake, but these are not the preferred option. For preventing aspiration in residents with dementia or other forms of cognitive impairment [13]. Therefore, more suitable interventions targeting residents with cognitive impairment are urgently needed.

The main limitation of this review is not including studies that were published in languages other than English and Chinese, which may cause publish bias as quantities of articles were published in other language. For future, this scoping review can perform as a precursor to several systematic reviews that focus on some specific interventions.

\section{Conclusion}

The majority of the included studies were conducted in developed countries or regions. The review provides a useful overview of interventions that have been used in nursing or residential facilities with older people who suffer from dysphagia, but the dearth of evidence from low to middle income countries is noticeable.
Professional interventions provided by speech and language therapists are still limited in the setting of nursing homes. Modification of diet was the most frequently used intervention to prevent or reduce aspiration, however, multi-disciplinary interventions were far better for aspiration management. Ideally residents should be offered person-centered interventions that have a comprehensive consideration of their degree of aspiration risk, health condition, individual feelings and cognitive state.

\section{Appendix 1}

\section{Search strategy}

Search date: 02 May 2020.

\section{Search strategy for MEDLINE (Ovid)}

\begin{tabular}{|c|c|c|}
\hline $\begin{array}{l}\text { Search } \\
\text { number }\end{array}$ & Search terms & Results \\
\hline 1 & exp Deglutition Disorders/ & 52,073 \\
\hline 2 & $\begin{array}{l}\text { (dysphagi* or orophargngeal dysphagia or } \\
\text { esophageal dysphagia or deglutition disorder* } \\
\text { or swallowing disorder or swallowing } \\
\text { dysfunction or swallowing problem* or } \\
\text { swallowing difficult: or difficulty in swallowing } \\
\text { or swallowing disabilit*).mp }\end{array}$ & 37,864 \\
\hline 3 & 1 or 2 & 67,773 \\
\hline 4 & exp Pneumonia, Aspiration/ & 5967 \\
\hline 5 & exp Respiratory Aspiration/ & 1412 \\
\hline 6 & exp Inhalation/ & 5645 \\
\hline 7 & $\begin{array}{l}\text { (aspiration or penetration or airway invasion or } \\
\text { aspiration pneumonia* or silent aspiration or } \\
\text { aspirator or choking).mp }\end{array}$ & 153,150 \\
\hline 8 & 4 or 5 or 6 or 7 & 157,920 \\
\hline 9 & exp Aged/ & $3,082,483$ \\
\hline 10 & exp "Aged, 80 and over"/ & 899,385 \\
\hline 11 & $\begin{array}{l}\text { (older persons or older adults or older people } \\
\text { or older patients or geriatric* or aged or aging } \\
\text { or older or elder or elderly or the elderly or } \\
\text { elderly people or senior*).mp }\end{array}$ & $5,679,572$ \\
\hline 12 & 9 or 10 or 11 & $5,679,572$ \\
\hline 13 & exp Early Medical Intervention/ & 2920 \\
\hline 14 & exp Disease Management/ & 68,664 \\
\hline 15 & exp Rehabilitation/ & 300,959 \\
\hline 16 & exp Rehabilitation Nursing/ & 1400 \\
\hline 17 & exp Therapeutics/ & $4,535,604$ \\
\hline 18 & $\begin{array}{l}\text { (intervention or management or treatment or } \\
\text { rehabilitation or therapy or strateg* or } \\
\text { program* or practice* or prevent* or control or } \\
\text { method* or texture modif* or bolus modif* or } \\
\text { diet modif* or food modif* or fluids modif* or } \\
\text { viscosity modif* or consistency modif* or } \\
\text { texture adapt* or thicken* or swallow* } \\
\text { maneuver* or swallow* posture* or chin down } \\
\text { or chin tuck or double deglutition or hard } \\
\text { swallow* or stimulation).mp }\end{array}$ & $16,704,201$ \\
\hline
\end{tabular}




\section{Search strategy for MEDLINE (Ovid) (Continued)}

\begin{tabular}{lll}
\hline $\begin{array}{l}\text { Search } \\
\text { number }\end{array}$ & Search terms & Results \\
\hline 19 & 13 or 14 or 15 or 16 or 17 or 18 & $17,494,545$ \\
20 & exp Residential Facilities/ & 51,952 \\
21 & $\begin{array}{l}\text { exp Nursing Homes/ } \\
\text { (nursing home* or residential care facilit* or }\end{array}$ & 38,848 \\
22 & $\begin{array}{l}\text { residential facilit* or aged care facilit* or elderly } \\
\text { care facilit* or long-term care facilit* or care }\end{array}$ \\
& $\begin{array}{l}\text { home or institution*).mp } \\
23\end{array}$ & 20 or 21 or 22 \\
24 & 3 and 8 and 12 and 19 and 23 & 354,267 \\
25 & Limit 24 to yr = "2010-Current" & 188 \\
\hline
\end{tabular}

\section{Search strategy for EMBASE (Ovid)}

\begin{tabular}{|c|c|}
\hline $\begin{array}{l}\text { Search } \\
\text { number }\end{array}$ & Search terms \\
\hline 1 & exp dysphagia/ \\
\hline 2 & $\begin{array}{l}\text { (dysphagi* or orophargngeal dysphagia or } \\
\text { esophageal dysphagia or deglutition disorder* } \\
\text { or swallowing disorder* or swallowing } \\
\text { dysfunction or swallowing problem* or } \\
\text { swallowing difficult* or difficulty in swallowing } \\
\text { or swallowing disabilit*).mp }\end{array}$ \\
\hline 3 & 1 or 2 \\
\hline 4 & $\begin{array}{l}\text { exp food aspiration/ or exp. aspiration/ or exp. } \\
\text { aspiration pneumonia/ or exp. pulmonary } \\
\text { aspiration/ or exp. liquid aspiration/ }\end{array}$ \\
\hline 5 & exp inhalation/ \\
\hline 6 & $\begin{array}{l}\text { (aspiration or penetration or airway invasion or } \\
\text { aspiration pneumonia* or silent aspiration or } \\
\text { aspirator or choking).mp }\end{array}$ \\
\hline 7 & 4 or 5 or 6 \\
\hline 8 & exp aged/ \\
\hline 9 & $\begin{array}{l}\text { (older persons or older adults or older people } \\
\text { or older patients or geriatric* or aged or aging } \\
\text { or older or elder or elderly or the elderly or } \\
\text { elderly people or senior*).mp }\end{array}$ \\
\hline 10 & 8 or 9 \\
\hline 11 & $\begin{array}{l}\text { exp nursing intervention/ or exp. early } \\
\text { intervention/ }\end{array}$ \\
\hline 12 & $\begin{array}{l}\text { exp nursing management/ or exp. disease } \\
\text { management/ or exp. health care } \\
\text { management/ or exp. medication therapy } \\
\text { management/ }\end{array}$ \\
\hline 13 & $\begin{array}{l}\text { exp rehabilitation nursing/ or exp. } \\
\text { rehabilitation/ }\end{array}$ \\
\hline 14 & exp therapy/ \\
\hline 15 & $\begin{array}{l}\text { (intervention or management or treatment or } \\
\text { rehabilitation or therapy or strateg* or } \\
\text { program* or practice* or prevent* or control or } \\
\text { method* or texture modif* or bolus modif* or } \\
\text { diet modif* or food modif* fluids modif* or } \\
\text { viscosity modif* or consistency modif* or } \\
\text { texture adapt* or thicken* or swallow* }\end{array}$ \\
\hline
\end{tabular}

80,527

83,487

52,547

\section{4,427}

283,322

26,116
2. Search strategy for EMBASE (Ovid) (Continued)

\begin{tabular}{|c|c|c|}
\hline $\begin{array}{l}\text { Search } \\
\text { number }\end{array}$ & Search terms & Results \\
\hline & $\begin{array}{l}\text { maneuver* or swallow* posture* or chin down } \\
\text { or chin tuck or double deglutition or hard } \\
\text { swallow* or stimulation).mp }\end{array}$ & \\
\hline 16 & 11 or 12 or 13 or 14 or 15 & $22,682,715$ \\
\hline 17 & $\begin{array}{l}\text { exp residential home/ or exp. home for the } \\
\text { aged/ }\end{array}$ & 17,582 \\
\hline 18 & exp nursing home/ & 51,106 \\
\hline 19 & $\begin{array}{l}\text { (nursing home* or residential care facilit* or } \\
\text { residential facilit* or aged care facilit* or elderly } \\
\text { care facilit* or long-term care facilit* or care } \\
\text { home or institution*).mp }\end{array}$ & 527,672 \\
\hline 20 & 17 or 18 or 19 & 535,977 \\
\hline 21 & 3 and 7 and 10 and 16 and 20 & 347 \\
\hline 22 & limit 21 to yr = "2010-Current" & 249 \\
\hline
\end{tabular}

\section{Search strategy for CINAHL (EBSCO)}

\begin{tabular}{lll}
\hline $\begin{array}{l}\text { Search } \\
\text { ID }\end{array}$ & Search terms & Results \\
\hline S1 & (MH "Deglutition Disorders") & 8910 \\
S2 & dysphagi* or orophargngeal dysphagia or & 14,200
\end{tabular}
esophageal dysphagia or deglutition disorder* or swallowing disorder* or swallowing dysfunction or swallowing problem* or swallowing difficult* or difficulty in swallowing or swallowing disabilit*

$\begin{array}{lll} & \text { S3 } & \text { S1 OR S2 } \\ 24,427 & \text { S4 } & (\text { MH "Pneumonia, Aspiration") } \\ 283,322 & \text { S5 } & (\text { MH "Aspiration") } \\ & \text { S6 } & \begin{array}{l}\text { aspiration or penetration or airway invasion or } \\ \text { aspiration pneumonia* or silent aspiration or } \\ \text { aspirator or choking }\end{array}\end{array}$
S4 OR S5 OR S6

(MH "Aged+")

S9 (MH "Aged, 80 and Over+")

S10 older persons or older adults or older people or older patients or geriatric* or aged or aging or older or elder or elderly or the elderly or elderly people or senior*

S11 S8 OR S9 OR S10 Interventions")

S13 (MH "Nursing Management+") OR (MH "Eating (MH "Rehabilitation+") OR (MH "Rehabilitation, Geriatric") OR (MH "Rehabilitation Nursing") rehabilitation or therapy or strateg* or program* or practice* or prevent* or control or method* or texture modif* or bolus modif* or diet modif* or food modif* or fluids modif* or viscosity modif* or 


\section{Search strategy for CINAHL (EBSCO) (Continued)}

\begin{tabular}{|c|c|c|}
\hline $\begin{array}{l}\text { Search } \\
\text { ID }\end{array}$ & Search terms & Results \\
\hline & $\begin{array}{l}\text { consistency modif* or texture adapt* or thicken* or } \\
\text { swallow* maneuver* or swallow* posture* or chin } \\
\text { down or chin tuck or double deglutition or hard } \\
\text { swallow* or stimulation }\end{array}$ & \\
\hline S17 & S12 OR S13 OR S14 OR S15 OR S16 & $4,879,368$ \\
\hline S18 & (MH “Nursing Homes+") & 29,768 \\
\hline S19 & (MH "Residential Facilities+") & 34,498 \\
\hline S20 & $\begin{array}{l}\text { nursing home }{ }^{*} \text { or residential care facilit* or } \\
\text { residential facilit* or aged care facilit* or elderly } \\
\text { care facilit* or long-term care facilit* or care home } \\
\text { or institution* }\end{array}$ & 213,983 \\
\hline S21 & S18 OR S19 OR S20 & 216,938 \\
\hline S22 & S3 AND S7 AND S11 AND S17 AND S21 & 113 \\
\hline S23 & S22Limiters - Published Date: 20100101-20,200,531 & 77 \\
\hline
\end{tabular}

\section{Search strategy for Cochrane library}

\begin{tabular}{|c|c|}
\hline $\begin{array}{l}\text { Search } \\
\text { number }\end{array}$ & Search terms \\
\hline \#1 & $\begin{array}{l}\text { MeSH descriptor: [Deglutition Disorders] explo } \\
\text { all trees }\end{array}$ \\
\hline \#2 & $\begin{array}{l}\text { dysphagi* or "orophargngeal dysphagia" or } \\
\text { "esophageal dysphagia" or deglutition NEXT } \\
\text { disorder* or swallowing NEXT disorder* or } \\
\text { "swallowing dysfunction" or swallowing NEXT } \\
\text { problem* or swallowing NEXT difficult* or } \\
\text { "difficulty in swallowing" or swallowing NEXT } \\
\text { disabilit* }\end{array}$ \\
\hline
\end{tabular}

\#3

\#4
\#1 or \#2 products

$$
\begin{aligned}
& \text { aspiration or penetration or "airway invasion" or } \\
& \text { aspiration NEXT pneumonia* or "silent } \\
& \text { aspiration" or aspirator or choking }
\end{aligned}
$$

\#4 or \#5 or \#6 or \#7

12,131

MeSH descriptor: [Aged] in all MeSH products

MeSH descriptor: [Aged, 80 and over] explode all trees

"older persons" or "older adults" or "older people" or "older patients" or geriatric* or aged or aging or older or elder or elderly or "the elderly" or "elderly people" or senior* explode all trees

MeSH descriptor: [Disease Management] explode all trees

\begin{tabular}{|c|c|c|}
\hline $\begin{array}{l}\text { Search } \\
\text { number }\end{array}$ & Search terms & Results \\
\hline & trees & \\
\hline \#16 & $\begin{array}{l}\text { MeSH descriptor: [Rehabilitation Nursing] } \\
\text { explode all trees }\end{array}$ & 54 \\
\hline$\# 17$ & MeSH descriptor: [Therapeutics] explode all trees & 298,062 \\
\hline \#18 & $\begin{array}{l}\text { intervention OR management OR treatment OR } \\
\text { rehabilitation OR therapy OR strateg* OR } \\
\text { program* OR practice* OR prevent* OR control } \\
\text { OR method* OR texture NEXT modif* OR bolus } \\
\text { NEXT modif* OR diet NEXT modif* OR food } \\
\text { NEXT modif* OR fluids NEXT modif* OR viscosity } \\
\text { NEXT modif* OR consistency NEXT modif* OR } \\
\text { texture NEXT adapt* OR thicken* OR swallow* } \\
\text { NEXT maneuver* OR swallow* NEXT posture* } \\
\text { OR "chin down" OR "chin tuck" OR "double } \\
\text { deglutition" OR hard NEXT swallow* OR } \\
\text { stimulation }\end{array}$ & $1,358,321$ \\
\hline
\end{tabular}

\section{Search strategy for Cochrane library (Continued)}

MeSH descriptor: [Residential Facilities] explode

MeSH descriptor: [Nursing Homes] explode all trees

nursing NEXT home* OR residential NEXT care NEXT facilit* OR residential NEXT facilit* OR aged NEXT care NEXT facilit* OR elderly NEXT care NEXT facilit* OR long-term NEXT care NEXT facilit* OR "care home" OR institution*

\begin{tabular}{|c|c|c|}
\hline $\begin{array}{l}\text { Search } \\
\text { ID }\end{array}$ & Search terms & Results \\
\hline$\# 1$ & $\begin{array}{l}\text { TOPIC: (dysphagi* or orophargngeal dysphagia or } \\
\text { esophageal dysphagia or deglutition disorder* or } \\
\text { swallowing disorder* or swallowing dysfunction or } \\
\text { swallowing problem* or swallowing difficult* or } \\
\text { difficulty in swallowing or swallowing disabilit*) }\end{array}$ & 33,132 \\
\hline \#2 & $\begin{array}{l}\text { TOPIC: (aspiration or penetration or airway } \\
\text { invasion or aspiration pneumonia* or silent } \\
\text { aspiration or aspirator or choking) }\end{array}$ & 303,245 \\
\hline \#3 & $\begin{array}{l}\text { TOPIC: (older persons or older adults or older } \\
\text { people or older patients or geriatric* or aged or } \\
\text { aging or older or elder or elderly or the elderly or } \\
\text { elderly people or senior*) }\end{array}$ & $4,239,844$ \\
\hline \#4 & $\begin{array}{l}\text { TOPIC: (intervention or management or treatment } \\
\text { or rehabilitation or therapy or strateg* or } \\
\text { program* or practice* or prevent* or control or } \\
\text { method* or texture modif* or bolus modif* or diet } \\
\text { modif* or food modif* or fluids modif* or viscosity } \\
\text { modif* or consistency modif* or texture adapt* or } \\
\text { thicken* or swallow* maneuver* or swallow* } \\
\text { posture* or chin down or chin tuck or double } \\
\text { deglutition or hard swallow* or stimulation) }\end{array}$ & $23,213,334$ \\
\hline
\end{tabular}
Jan 2010 to May 2020

\section{Search strategy for web of science}




\section{Search strategy for web of science (Continued)}

\begin{tabular}{|c|c|c|}
\hline $\begin{array}{l}\text { Search } \\
\text { ID }\end{array}$ & Search terms & Results \\
\hline \#5 & $\begin{array}{l}\text { TOPIC: (nursing home* or residential care facilit* } \\
\text { or residential facilit* or aged care facilit* or elderly } \\
\text { care facilit* or long-term care facilit* or care home } \\
\text { or institution*) }\end{array}$ & 687,070 \\
\hline \#6 & \#5 AND \#4 AND \#3 AND \#2 AND \#1 & 213 \\
\hline \#7 & $\begin{array}{l}\text { \#6Refined by: PUBLICATION YEARS: (2020 OR } 2013 \\
\text { OR } 2019 \text { OR } 2012 \text { OR } 2018 \text { OR } 2011 \text { OR } 2017 \text { OR } \\
2010 \text { OR } 2016 \text { OR } 2015 \text { OR 2014) }\end{array}$ & 142 \\
\hline
\end{tabular}

\section{Appendix 2}

Table 3 Data extraction tool

\section{Reviewer \\ Date \\ Scoping review details \\ Scoping review title \\ Review objective/s \\ Review question/s}

\section{Inclusion/exclusion criteria}

Population

Concept

Context

\section{Study details and characteristics}

Author(s)
Year
Title
Journal
Study design
Country/Region
Aim/Purpose
Setting
Participants
Sample

\section{Details/results extracted from study}

Types of intervention

Intervention providers

Target residents of intervention

Locations of intervention

Results of intervention

Other key findings

\section{Abbreviations}

VFSS: Video Fluoroscopic Swallowing Study; PRISMA-SR: Systematic Reviews and Meta-Analyses extension for Scoping Reviews; JBI: Joanna Briggs Institute; JBI-SUMARI: Joanna Briggs Institute System for the Unified Management, Assessment and Review of Information; SLTs: Speech and language therapists; PEG: Polyethylene glycol 3350 laxative

\section{Acknowledgments}

We gratefully acknowledge Samantha Brown from University of Plymouth for guiding us to design the search strategy.

\section{Authors' contributions}

All authors took part in the entire study and approved final manuscript. CS and $\mathrm{KB}$ contributed to the study design; $\mathrm{CS}, \mathrm{KB}$ and $\mathrm{CY}$ were responsible for database search; CS and KB conducted study selection and data extraction; CS drafted the manuscript; KB and CY critically revised manuscript for important intellectual content.

\section{Funding}

This work was sponsored by Postgraduate Research \& Practice Innovation Program of Jiangsu Province (No. SJKY19_1343) and 2020 PhD training program under UK-Jiangsu $20+20$ world class university consortium. Both funds came from Jiangsu Education Department. The sponsors had no role in the design and conduct of this work.

\section{Availability of data and materials}

Our data or material may be available from corresponding author or first author upon reasonable request.

\section{Declarations}

Ethics approval and consent to participate

Not applicable.

\section{Consent for publication \\ Not applicable.}

\section{Competing interests}

The authors declare that they have no competing interests.

\section{Author details}

${ }^{1}$ School of Nursing, Nanjing Medical University, Nanjing, China. ${ }^{2}$ The University of Plymouth Centre for Innovations in Health and Social Care: A Joanna Briggs Institute Centre of Excellence, Plymouth, UK. ${ }^{3}$ School of Nursing and Midwifery, University of Plymouth, Plymouth, UK.

Received: 21 October 2020 Accepted: 29 June 2021

Published online: 17 July 2021

\section{References}

1. Baijens LW, Clavé P, Cras P, Ekberg O, Forster A, Kolb GF, et al. European society for swallowing disorders - European Union geriatric medicine society white paper: oropharyngeal dysphagia as a geriatric syndrome. Clin Interv Aging. 2016;11:1403-28. https://doi.org/10.2147/CIA.S107750.

2. Cook IJ, Kahrilas PJ. AGA technical review on management of oropharyngeal dysphagia. Gastroenterology. 1999;116(2):455-78. https://doi. org/10.1016/50016-5085(99)70144-7.

3. Madhavan A, LaGorio LA, Crary MA, Dahl WJ, Carnaby GD. Prevalence of and risk factors for dysphagia in the community dwelling elderly: a systematic review. J Nutr Health Aging. 2016;20(8):806-15. https://doi.org/1 0.1007/s12603-016-0712-3.

4. Park YH, Han HR, Oh BM, Lee J, Park JA, Yu SJ, et al. Prevalence and associated factors of dysphagia in nursing home residents. Geriatr Nurs. 2013;34(3):212-7. https://doi.org/10.1016/j.gerinurse.2013.02.014.

5. Lin LC, Wu SC, Chen HS, Wang TG, Chen MY. Prevalence of impaired swallowing in institutionalized older people in Taiwan. J Am Geriatr Soc. 2002;50(6):1118-23. https://doi.org/10.1046/j.1532-5415.2002.50270.x.

6. Sura L, Madhavan A, Carnaby G, Crary MA. Dysphagia in the elderly: management and nutritional considerations. Clin Interv Aging. 2012;7:28798. https://doi.org/10.2147/CIA.S23404. 
7. Mann G, Hankey GJ, Cameron D. Swallowing disorders following acute stroke: prevalence and diagnostic accuracy. Cerebrovasc Dis. 2000;10(5):3806. https://doi.org/10.1159/000016094.

8. Bergman H, Ferrucci L, Guralnik J, Hogan DB, Hummel S, Karunananthan S, et al. Frailty: an emerging research and clinical paradigm-issues and controversies. J Gerontol A Biol Sci Med Sci. 2007;62(7):731-7. https://doi. org/10.1093/gerona/62.7.731.

9. Logemann JA, Gensler G, Robbins J, Lindblad AS, Brandt D, Hind JA, et al. A randomized study of three interventions for aspiration of thin liquids in patients with dementia or Parkinson's disease. J Speech Lang Hear Res. 2008;51(1):173-83. https://doi.org/10.1044/1092-4388(2008/013).

10. Hickson M, Frost G. An investigation into the relationship between quality of life, nutritional status and physical function. Clin Nutr. 2004;23(2):213-21. https://doi.org/10.1016/S0261-5614(03)00127-4.

11. Serra-Prat M, Palomera M, Gomez C, Sar-Shalom D, Saiz A, Montoya JG, et al. Oropharyngeal dysphagia as a risk factor for malnutrition and lower respiratory tract infection in independently living older persons: a population-based prospective study. Age Aging. 2012;41(3):376-81. https:// doi.org/10.1093/ageing/afs006.

12. Stookey JD, Pieper CF, Cohen HJ. Is the prevalence of dehydration among community-dwelling older adults really low? Informing current debate over the fluid recommendation for adults aged $70+$ years. Public Health Nutr. 2005;8(8):1275-85. https://doi.org/10.1079/PHN2005829.

13. Morley JE. Dysphagia and aspiration. J Am Med Dir Assoc. 2015;16(8):631-4. https://doi.org/10.1016/j.jamda.2015.05.022.

14. Wirth R, Pourhassan M, Streicher M, Hiesmayr M, Schindler K, Sieber CC, et al. The impact of dysphagia on mortality of nursing home residents: results from the NutritionDay project. J Am Med Dir Assoc. 2018;19(9):775-8. https://doi.org/10.1016/j.jamda.2018.03.016.

15. Verdonschot RJ, Baijens LW, Serroyen JL, Leue C, Kremer B. Symptoms of anxiety and depression assessed with the hospital anxiety and depression scale in patients with oropharyngeal dysphagia. J Psychosom Res. 2013; 75(5):451-5. https://doi.org/10.1016/j.jpsychores.2013.08.021.

16. Ebihara S, Sekiya H, Miyagi M, Ebihara T, Okazaki T. Dysphagia, dystussia, and aspiration pneumonia in elderly people. J Thorac Dis. 2016;8(3):632-9. https://doi.org/10.21037/jtd.2016.02.60.

17. Smith CH, Logemann JA, Colangelo LA, Rademaker AW, Pauloski BR. Incidence and patient characteristics associated with silent aspiration in the acute care setting. Dysphagia. 1999;14(1):1-7. https://doi.org/10.1007/ PL00009579.

18. Garon BR, Sierzant T, Ormiston C. Silent aspiration: results of 2,000 video fluoroscopic evaluations. J Neurosci Nurs. 2009;41(4):178-85. https://doi. org/10.1097/JNN.0b013e3181aaaade.

19. Nobrega AC, Rodrigues $B$, Melo A. Is silent aspiration a risk factor for respiratory infection in Parkinson's disease patients. Parkinsonism Relat Disord. 2008;14(8):646-8. https://doi.org/10.1016/j.parkreldis.2007.12.007.

20. Cabre M, Serra-Prat M, Palomera E, Almirall J, Pallares R, Clave P. Prevalence and prognostic implications of dysphagia in elderly patients with pneumonia. Age Ageing. 2010;39(1):39-45. https://doi.org/10.1093/ageing/a fp100.

21. Almirall J, Cabre M, Clave P. Complications of oropharyngeal dysphagia: aspiration pneumonia. Nestle Nutr Inst Workshop Ser. 2012;72:67-76. https://doi.org/10.1159/000339989.

22. Clave P, Rofes L, Carrion S, Ortega O, Cabre M, Serra-Prat M, et al. Pathophysiology, relevance and natural history of oropharyngeal dysphagia among older people. Nestle Nutr Inst Workshop Ser. 2012;72:57-66. https:// doi.org/10.1159/000339986.

23. Peters MDJ, Godfrey C, Mclnerney P, Baldini Soares C, Khalil H, Parker D. Chapter 11: Scoping Reviews. In: Aromataris E, Munn Z, editors. Joanna Briggs Institute Reviewer's Manual. The Joanna Briggs Institute; 2017. Available from https://reviewersmanual.joannabriggs.org/.

24. Tricco AC, Lillie E, Zarin W, O'Brien KK, Colquhoun H, Levac D, et al. PRISMA extension for scoping reviews (PRISMA-SCR): checklist and explanation. Ann Intern Med. 2018;169(7):467-73. https://doi.org/10.7326/M18-0850

25. Cormary X, Tannou Y, Bras M, Culis M, Cugy E, Blasco-Baque V. Pleasure of eating despite dysphagia in nursing homes : a multi-disciplinary plan. Dysphagia. 2018;33(4):540.

26. Freiry AM, De Matos DM, Haack BG, Olchik MR, Ghisi M. Efficacy of an intervention program in elderly with dysphagia and dementia resident longterm institution: A series of cases. Int Arch Otorhinolaryngol. 2017;21(2):S122.
27. Gilmore-Bykovskyi AL, Rogus-Pulia N. Temporal associations between caregiving approach, behavioral symptoms and observable indicators of aspiration in nursing home residents with dementia. J Nutr Health Aging. 2018;22(3):400-6. https://doi.org/10.1007/s12603-017-0943-y.

28. Gokula M, Rubeen S, Thotakura S. Does amantadine help elderly residents with symptomless dysphagia? Ann Long-Term Care. 2011;19(5):37-40.

29. Hagglund $P$, Hagg M, Wester $P$, Levring JE. Effects of oral neuromuscular training on swallowing dysfunction among older people in intermediate care-a cluster randomised, controlled trial. Age Ageing. 2019;48(4):533-40. https://doi.org/10.1093/ageing/afz042.

30. Hajjar S, Wollman D. Resident presentation dysphagia in elderly. J Am Geriatr Soc. 2019;67, S278(1):-S279.

31. Kuramoto N, Jayatilake D, Hidaka K, Suzuki K. Automatic measurements of neck flexion using smartphone-based swallowing monitor. Dysphagia. 2018; 33(4):564.

32. Levenson SA, Walker VL. It is time to revamp approaches to managing dysphagia in nursing homes. J Am Med Dir Assoc. 2019;20(8):952-5. https:// doi.org/10.1016/j.jamda.2019.06.005.

33. Luk JKH, Chan DKY. Preventing aspiration pneumonia in older people: do we have the 'know-how'? Hong Kong Medical Journal. 2014;20(5):421-7. https://doi.org/10.12809/hkmj144251.

34. Mesioye A, Smith J, Zilberstein M, Hart H, Bush-Thomas P, Ward M. Dysphagia rounds: Interdisciplinary collaboration to improve swallowing safety in a VA community living center. J Am Geriatr Soc. 2018;66(2):S192.

35. Hines S, McCrow J, Abbey J, Gledhill S. Thickened fluids for people with dementia in residential aged care facilities. Int J Evid Based Healthcar. 2010; 8(4):252-5. https://doi.org/10.1111/j.1744-1609.2010.00188.x.

36. Painter V, Le Couteur DG, Waite LM. Texture-modified food and fluids in dementia and residential aged care facilities. Clin Interv Aging. 2017;12: 1193-203. https://doi.org/10.2147/CIA.S140581.

37. Park Y, Oh S, Chang H, Bang HL. Effects of the evidence-based nursing care algorithm of dysphagia for nursing home residents. J Gerontol Nurs. 2015; 41(11):30-9. https://doi.org/10.3928/00989134-20151015-04.

38. Richards E. Communication and swallowing problems after stroke. Nurs Residential Care. 2012;14(6):282-6. https://doi.org/10.12968/nrec.2012.14.6.282.

39. Yamada T, Matsuo K, Izawa M, Yamada S, Masuda Y, Ogasawara T. Effects of age and viscosity on food transport and breathing-swallowing coordination during eating of two-phase food in nursing home residents. Geriatr Gerontol Int. 2017;17(11):2171-7. https://doi.org/10.1111/ggi.13056.

40. Lu M, Hong L, He LM, Gao F, Xu J, Jiang LN. Effect of community nursing intervention in elderly people with dysphagia in nursing homes. Shanghai Med Pharm J. 2018;39(6):33-5,53.

41. Chiang CK, Hwu YJ. Feeding experiences of nursing aides for residents with dysphagia. Geriatr Nurs. 2018;39(4):436-42. https://doi.org/10.1016/j. gerinurse.2017.12.016.

42. Takamoto K, Saitoh T, Taguchi T, Nishimaru H, Urakawa S, Sakai S, et al. Lip closure training improves eating behaviors and prefrontal cortical hemodynamic activity and decreases daytime sleep in elderly persons. J Bodyw Mov Ther. 2018;22(3):810-6. https://doi.org/10.1016/j.jbmt.2017.09.002.

43. Chen S, Cui Y, Ding Y, Sun C, Xing Y, Zhou R, et al. Prevalence and risk factors of dysphagia among nursing home residents in eastern China: a cross-sectional study. BMC Geriatr. 2020;20(1):352. https://doi.org/10.1186/ s12877-020-01752-z.

44. Ministry of Civil Affairs of the People's Republic of China. Social services development statistical communique in 2017. Beijing: Ministry of Civil Affairs of the People's Republic of China; 2018. http://www.mca.gov.cn/article/sj/ tjgb/2017/201708021607.pdf

45. Beverly C, Burger SG, Maas ML, Specht JK. Aging issues: nursing imperatives for healthcare reform. Nurs Adm Q. 2010;34(2):95-109. https://doi.org/10.1 097/NAQ.0b013e3181d91718.

46. Beck AM, Kjaersgaard A, Hansen T, Poulsen I. Systematic review and evidence based recommendations on texture modified foods and thickened liquids for adults (above 17 years) with oropharyngeal dysphagiaan updated clinical guideline. Clin Nutr. 2018;37(6):1980-91. https://doi. org/10.1016/j.clnu.2017.09.002.

47. O'Keeffe ST. Use of modified diets to prevent aspiration in oropharyngeal dysphagia: is current practice justified? BMC Geriatr. 2018;18(1):167. https:// doi.org/10.1186/s12877-018-0839-7.

48. Carlisle BJ, Craft G, Harmon JP, Ilkevitch A, Nicoghosian J, Sheyner I, et al. PEG and Thickeners: a critical interaction between polyethylene glycol 
laxative and starch-based Thickeners. J Am Med Dir Assoc. 2016;17(9):860-1. https://doi.org/10.1016/j.jamda.2016.06.024.

49. Ebihara S, Ebihara T. Cough in the elderly: a novel strategy for preventing aspiration pneumonia. Pulm Pharmacol Ther. 2011;24(3):318-23. https://doi. org/10.1016/j.pupt.2010.10.003.

50. Logemann JA, Gensler G, Robbins J, Lindblad AS, Brandt D, Hind JA, et al. A randomized study of three interventions for aspiration of thin liquids in patients with dementia or Parkinson's disease. J Speech Lang Hear Res. 2008:51(1):173-83. https://doi.org/10.1044/1092-4388(2008/013).

51. Terré $R$, Mearin F. Effectiveness of chin-down posture to prevent tracheal aspiration in dysphagia secondary to acquired brain injury: a videofluoroscopy study. Neurogastroenterol Motil. 2012;24(5):414-9. https:// doi.org/10.1111/j.1365-2982.2011.01869.x.

52. Solazzo A, Monaco L, Del Vecchio L, Tamburrini S, lacobellis F, Berritto D, et al. Investigation of compensatory postures with videofluoromanometry in dysphagia patients. World J Gastroenterol. 2012;18(23):2973-8. https://doi. org/10.3748/wjg.v18.i23.2973.

53. Rofes L, Arreola V, Almirall J, Cabré M, Campins L, García-Peris P, et al. Diagnosis and management of oropharyngeal dysphagia and its nutritional and respiratory complications in the elderly. Gastroenterol Res Pract. 2011;2011:818979.

54. Sze WP, Yoon WL, Escoffier N, Rickard Liow SJ. Evaluating the training effects of two swallowing rehabilitation therapies using surface electromyography-Chin Tuck against resistance (CTAR) exercise and the shaker exercise. Dysphagia. 2016;31(2):195-205. https://doi.org/10.1007/s004 55-015-9678-2.

55. Cabre M, Serra-Prat M, Palomera E, Almirall J, Pallares R, Clavé P. Prevalence and prognostic implications of dysphagia in elderly patients with pneumonia. Age Ageing. 2010;39(1):39-45. https://doi.org/10.1093/ageing/afp100.

56. Rofes L, Arreola V, López I, Martin A, Sebastián M, Ciurana A, et al. Effect of surface sensory and motor electrical stimulation on chronic poststroke oropharyngeal dysfunction. Neurogastroenterol Motil. 2013;25(11):888-e701. https://doi.org/10.1111/nmo.12211.

57. Olchik MR, Rech RS, Jacinto-Scudeiro LA, Mello AM, Santos VB. The effects of orofacial thermal-tactile stimulation on elderly long-term-care facility residents with severe dementia: a case series. Audiol Commun Res. 2020;25: e2334. https://doi.org/10.1590/2317-6431-2020-2334.

58. Waldron C, Nunn J, Mac Giolla Phadraig C, Comiskey C, Guerin S, van Harten MT, et al. Oral hygiene interventions for people with intellectual disabilities. Cochrane Database Syst Rev. 2019;5(5):CD012628.

\section{Publisher's Note}

Springer Nature remains neutral with regard to jurisdictional claims in published maps and institutional affiliations.

Ready to submit your research? Choose BMC and benefit from:

- fast, convenient online submission

- thorough peer review by experienced researchers in your field

- rapid publication on acceptance

- support for research data, including large and complex data types

- gold Open Access which fosters wider collaboration and increased citations

- maximum visibility for your research: over $100 \mathrm{M}$ website views per year

At BMC, research is always in progress.

Learn more biomedcentral.com/submissions 